\title{
STUDY OF SERUM FERRITIN IN SMOKERS
}

\section{MEERA SHIVASEKAR*, VINODHINI VM, RUPESH KUMAR Y}

Department of Biochemistry, SRM Medical College Hospital and Research Centre, SRM University, Kattankulathur, Tamil Nadu, India. Email: mshivasekar@gmail.com

Received: 22 July 2017, Revised and Accepted: 09 October 2017

\section{ABSTRACT}

Objective: Cigarette smoking is a major global public health problem and increases in the prevalence of tobacco smoking is the cause premature death worldwide. Serum ferritin an intracellular protein that can store and release iron is considered to be one of the important clinical biomarkers to evaluate iron status. This study explores the effect of cigarette smoking on serum ferritin level.

Methods: The study was carried out in 100 cigarette smokers and 100 nonsmokers.

Results: Subjects with smoking habits showed a significant increase in the serum ferritin levels compared to nonsmokers. Serum iron level, as well as total iron-binding capacity, showed significant increase compared with nonsmokers. Serum ferritin is found to correlate with serum iron.

Conclusion: This study supports the fact that cigarette smoking has adverse effect on serum ferritin and other hematologic parameters, and serum ferritin is one of the most reliable indicators of iron status.

Keywords: Cigarette, Hematologic parameters, Smokers.

(C) 2018 The Authors. Published by Innovare Academic Sciences Pvt Ltd. This is an open access article under the CC BY license (http://creativecommons. org/licenses/by/4. 0/) DOI: http://dx.doi.org/10.22159/ajpcr.2018.v11i1.21502

\section{INTRODUCTION}

Cigarette smoking is an important and independent risk factor for atherosclerosis, coronary artery disease, and peripheral vascular disease [1]. Several studies have shown that cigarette contains carcinogen, irritant substance carbon monoxide, and other gases which can harm lipids, proteins, and also causes DNA damage. Cigarette smoking has increasing effect on hemoglobin concentration which is proportional to the amount of cigarette smoked per day. Ferritin is a globular protein complex containing 24 protein units and a primary intracellular iron storage protein in the cell keeps iron in a soluble and nontoxic form. Ferritin, an acute phase protein, is elevated in chronic inflammation, liver disorders [2]. Serum ferritin is generally a reliable indicator of iron status commonly used to diagnose iron deficiency and also indicates the presence of iron overload. Hence, serum ferritin is considered as one of the most important tools in the measurement of the state of iron balance [3]

\section{METHODS}

This cross-sectional study was performed in accordance with the approval of the Institutional Ethics Committee (ECN: 739/ IEC/2015) and informed written consent was obtained from all subjects.

The study was conducted between two group smokers and nonsmokers. All were apparently healthy male subjects between the age group of 25-45 years. The total sample size was 200 out of which the study group includes smokers $(n=100)$ and control group includes nonsmokers $(\mathrm{n}=100)$. The study group was smoking filtered cigarette minimum 5 (maximum 10) per day with duration $\leq 10$ years. The socialeconomic status, age, height, and weight, was compared between study group and nonsmokers. Subjects suffering from coagulation disorders taking medication like aspirin, non-steroids were excluded. All subjects were free from other habits such as tobacco chewing and alcohol intake. Written informed consent was obtained from all subjects before the procedure.

\section{Sample collection}

Venous blood was collected from participants after an overnight $12 \mathrm{~h}$ fast $3 \mathrm{ml}$ of blood collected in plan vacutainer and allowed to clot and serum was separated by centrifugation at 3000 RPM for $10 \mathrm{~min}$.

Serum ferritin was measured by using immunofluorometric method and iron, total iron-binding capacity (TIBC) was measured using standard kits in Beckmann coulter auto-analyzer AU 400 on the same day of sample collection.

\section{Statistical analysis}

The results are presented as mean \pm standard deviation comparison was made between two groups using Student's t-test. $p<0.001$ is considered statistically significant.

\section{RESULTS}

Subjects with smoking habits showed a significant increase in serum ferritin level $(48.82 \pm 21,256 \pm 23)$ when compared with the control group (Table 1). Serum iron level also showed significant increase along with TIBC compared to control group. Serum ferritin was found to correlate positively with serum iron (Table 2). Hemoglobin level also was found to be significantly increased in smokers compared to nonsmokers.

\section{DISCUSSION}

Ferritin is the primary iron storage protein in tissues and also an acute phase reactant. Its level is found to be elevated in many chronic conditions, infection, and liver disease [4]. Serum ferritin determination provides direct measurement of total body iron store and thus helps in the differentiation between iron deficiency anemia and anemia due to chronic infection or inflammation [5].

High serum ferritin level in smokers is shown to be associated with increased risk of acute myocardial infarction [6]. In our study, significant 
Table 1: Comparison of ferritin and iron status between smokers and non-smokers

\begin{tabular}{llll}
\hline Parameters & $\begin{array}{c}\text { Smokers } \\
(\mathbf{n = 1 0 0})\end{array}$ & $\begin{array}{l}\text { Non-smokers } \\
(\mathbf{n = 1 0 0})\end{array}$ & p value \\
\hline Serum ferritin $(\mu \mathrm{g} / \mathrm{dl})$ & $256 \pm 24$ & $48 \pm 22$ & $<0.001^{*}$ \\
Serum iron $(\mu \mathrm{g} / \mathrm{dl})$ & $209 \pm 32$ & $116 \pm 30$ & $<0.001^{*}$ \\
TIBC $(\mu \mathrm{g} / \mathrm{dl})$ & $321 \pm 24$ & $232 \pm 22$ & $<0.001^{*}$ \\
Hemoglobin $(\mathrm{gm} / \mathrm{dl})$ & $14 \pm 0.8$ & $13 \pm 1.4$ & $<0.01^{*}$ \\
\hline
\end{tabular}

Values are expressed as mean \pm standard deviation. The values are statistically significant if $\mathrm{p}<0.001$. TIBC: Total iron-binding capacity

Table 2: The Pearson's correlation analysis between serum ferritin and iron in smokers

\begin{tabular}{lll}
\hline Parameters & Mean \pm SD & r(p) \\
\hline Serum Ferritin $(\mu \mathrm{g} / \mathrm{dl})$ & $256 \pm 24$ & $\mathrm{r}=0.156(0.432)$ \\
Serum Iron $(\mu \mathrm{g} / \mathrm{dl})$ & $209 \pm 32$ & \\
\hline
\end{tabular}

SD: Standard deviation

increase in mean level of serum ferritin is observed in smokers compared to nonsmokers and ferritin level correlated positively with iron

Ferritin is a positive acute phase protein concentration increases during inflammation and no longer reflects iron store and only reflects iron overload in the absence of disease [7]. However, serum ferritin is positively and hemoglobin is negatively associated with inflammation and infection. Smoking and drinking are also associated with increase in the level of serum ferritin [8].

Serum ferritin concentration is directly proportional to intracellular ferritin concentration and indicates the measure of body iron store. Body iron storage increases in male with proportional rise in serum ferritin. Excessive iron is capable of stimulating the progression of atherosclerotic lesions by reducing the levels of antioxidants in the plasma by increasing the production of free radical and promotes lipid peroxidation [9]. Serum ferritin is also a predictor of metabolic syndrome [10].

Serum ferritin measurement is widely used in clinical medicine as a diagnostic test to detect iron storage disease or as a marker of some neoplastic disease. Patients with hematological disease had increased accumulation of iron which was found to affect the synthesis and secretion of insulin by the pancreas and results in the development of insulin resistance [11]. The increased hemoglobin concentration observed in smokers is due to inhaled carbon monoxide resulting in the formation of carboxyhemoglobin which reduces the oxyhemoglobin level in smokers [12]. High serum ferritin is not only a marker of iron store but also an indicator of inflammation and oxidative stress [13]. Thus, the finding showed that smoking has significant impact on hemoglobin concentration and ferritin a ubiquitous intracellular protein that can store and release iron acts as a buffer against iron deficiency and iron overload can be widely used as a clinical biomarker to evaluate iron status.

\section{CONCLUSION}

The study supports the fact that cigarette smoking produces adverse effect on serum ferritin and other hematological parameters and also supports the fact that serum ferritin is considered to be one of the most important clinical biomarkers to evaluate iron status.

\section{REFERENCES}

1. Nordenberg D, Yip R, Binkin NJ. The effect of cigarette smoking on hemoglobin levels and anemia screening. JAMA 1990;264:1556-9.

2. Al-Awadhi AM, AlFadhli SM, Mustafa NY, Sharma PN. Effects of cigarette smoking on hematological parameters and von Willebrand factor functional activity levels in asymptomatic male and female Arab smokers. Med Princ Pract 2008;17:149-53

3. Jehn M, Clark JM, Guallar E. Serum ferritin and risk of the metabolic syndrome in U.S. adults. Diabetes Care 2004;27:2422-8.

4. Lapenna D, de Gioia S, Mezzetti A, Ciofani G, Consoli A, Marzio L, et al. Cigarette smoke, ferritin, and lipid peroxidation. Am J Respir Crit Care Med 1995;151:431-5.

5. Cook JD, Lipschitz DA, Miles LE, Finch CA. Serum ferritin as a measure of iron states in normal subjects. MJ Clin Nutr 1974;271:681-7.

6. Stone RE, Nankap M, Ndjebayi AO, Erhardt JG, Brown PH. Plasma ferritin and soluble transferring receptors concentration and body iron stores identify similar risk factors for iron deficiency but result in different estimates of the national prevalence of iron deficiency among women. J Nutr 2013;143:369-77.

7. Bataller R. Time to ban smoking in patients with chronic liver diseases. Hepatology 2006;44:1394-6.

8. Lee CH, Goag EK, Lee SH, Chung KS, Jung JY, Park MS, et al. Association of serum ferritin levels with smoking and lung function in the Korean adult population: Analysis of the fourth and fifth Korean national health and nutrition examination survey. Int J Chron Obstruct Pulmon Dis 2016;11:3001-6.

9. Shivashekar M, Ramachandran K, William E. Response of ferritin to oxidative stress in Rheumatoid arthritis. Asian J Pharm Clin Res 2014;7 Suppl 1:93-4.

10. Sharma P, Kumar P, Sharma R, Kishore K, Sharma G. Assessment of metabolic syndrome: Role of serum ferritin. Asian J Pharm Clin Res 2016;9:240-3

11. Cabello-Verrugio C, Ruiz-Ortega M, Mosqueira M, Simon F. Oxidative stress in disease and aging: Mechanisms and therapies. Claudio cabelloverrugio,1,2 Marta ruiz-ortega,3 Matias mosqueira,4 and Felipe Simon. Int J Pharm Pharm Sci 2016;3:2.

12. Brownell A, Lowson S, Bronzovic M. Serum ferritin concentration in sickle cell crises. J Clin Pathol 1986;39:359-78.

13. Maithreyi R, Janani AV, Krishna R, Shwetha A, Edwin RR, Mohan SK. Erythrocyte lipid peroxidation and antioxidant in chronic alcoholics with alcoholic liver disease. Asian J Pharm Clin Res 2010;3:181-5. 